\title{
INFLUENCE OF A NEW DERIVATIVE OF 4-AMINOBUTANOIC ACID ON THE LEVEL OF NEUROMEDIATORY AMINOACIDS, NEUROMEDIATORS AND THE STATE OF THE RATS' HYPOCAMP IN CONDITIONS OF BRAIN ISCHEMIA
}

\author{
Oksana Mishchenko, Natalia Palagina, Yulia Larianovska, Tetyana Gorbach, \\ Victor Khomenko, Nataliia Yasna
}

\begin{abstract}
The aim: to investigate the effect of a new derivative of 4-aminobutanoic acid (compounds KGM-5) on the level of neurotransmitters and neurotransmitter amino acids and the structural-functional state of the hippocampus of rats with acute cerebrovascular accident (ACVA).

Materials and methods. ACVA was reproduced in rats by occlusion of the left carotid artery under anesthesia (sodium thiopental (35 $\mathrm{mg} / \mathrm{kg})$ intraperitoneally (i/p). 5 groups of animals were used: intact control $(I C, n=6)$, untreated animals with ACVA (CP, $n=13)$; animals with ACVA $(n=14)$, which were treated for 5 days with KGM-5 at a dose of 30 $\mathrm{mg} / \mathrm{kg} \mathrm{i} / \mathrm{p}$, animals with ACVA ( $\mathrm{n}=13)$, who received i/p comparison drug "Picamilon" (17 mg/kg). There was a group of pseudo-operated animals (POA, $n=8)$. Withdrawal of animals from the experiment was performed on day 6 after modeling ACVA by painless euthanasia under anesthesia. Histological examinations of $C A_{1}$ and $C A_{3}$ zones of the ventral hippocampus were performed with staining of sections with thionine by the method of Nissl and hematoxylin, eosin. In the rat brain, neurotransmitter amino acids and neurotransmitters were identified. Statistical processing was performed using the W-Shapiro-Wills test to verify the normality of the distribution and the nonparametric MannWhitney $U$-test. The accepted significance level is $p<0.05$.

Results. Under the influence of the compound KGM-5 and "Picamilon" in the CA $A_{1}$ zone of the hippocampus, the number of normochromic neurons increased by $20 \%$ and $16.6 \%$, respectively, hyperchromic pycnomorphic neurons and shadow cells decreased respectively by 5.8; 2.9 times and 6.3; 3.5 times, the index of alteration of neurons decreased by 6 times and 4.8 times, respectively, the area of the perikaryon of these neurons increased by $39.7 \%$ and $77.8 \%$, respectively, compared with $K P(p<0.05)$. Both studied agents showed a less pronounced normalizing effect on the $\mathrm{CA}_{3}$ area of the hippocampus. The new compound KGM-5 showed a normalizing effect similar to "Picamilon" on the level of neurotransmitter amino acids and neurotransmitters in the brain of rats with ACVA.

Conclusions. Therapeutic administration of KGM-5 increases the survival of ventral hippocampal neurons, reducing the relative proportion of irreversibly altered cells, and helps to restore impaired levels of neurotransmitter amino acids and neurotransmitters in the brain of rats with ACVA.

The neuroprotective effect of the new compound KGM-5 corresponds to this comparison drug "Picamilon"
\end{abstract}

Keywords: new derivative of 4-aminobutanoic acid, brain ischemia, neuroprotective effect, hippocampus, Picamilon

How to cite:

Mishchenko, O., Palagina, N., Larianovska, Yu., Gorbach, T., Khomenko, V., Yasna, N. (2021). Influence of a new derivative of 4-aminobutanoic acid on the level of neuromediatory aminoacids, neuromediators and the state of the rats' hypocamp in conditions of brain ischemia. ScienceRise: Pharmaceutical Science, 2 (30), 64-71. doi: http://doi.org/10.15587/2519-4852.2021.230305

(C) The Author(s) 2021

This is an open access article under the Creative Commons CC BY license

\section{Introduction}

Cognitive impairment is one of the most important medical and social problems [1-3]. The urgency of this problem is steadily growing in connection with demographic trends that have occurred in recent decades, namely the increase in life expectancy and the growing share of the elderly in the population. The main diseases of the brain that cause the development of cognitive dysfunction are neurodegenerative (Alzheimer's disease, etc.), vascular (cerebral ischemia), traumatic brain injury, neuroinfections and others [1-4]. Cerebrovascular disorders are the second most common cause of dementia after Alzheimer's disease [1]. Vascular disorders lead to changes in cerebral blood flow with the development of hypoxia of brain tissues, with impaired nutrition and energy supply of neurons, which contributes to the development of intracellular biochemical changes and diffuse multifocal brain damage [5]. For the treatment of cognitive disorders in complex therapy are widely used cerebroprotectors, nootropics, which are not always effective and safe [6]. In this regard, the search for new safer and more effective nootropic drugs, in particular GABA derivatives, capable of improving cognitive impairment resulting from acute or chronic cerebrovascular accident, is an urgent scientific task. Promising in this regard are new derivatives of 4aminobutanoic acid, synthesized at the National University of Pharmacy, among 11 of which was selected the leading substance for anti-amnestic activity under the code KGM-5, which also exhibits antihypoxic activity [7]. Given the above, it is appropriate to study its ability to improve the impaired state of the brain of rats, in particular the hippocampus, and to influence the level of neurotransmitters 
and neurotransmitter amino acids in the conditions of experimental cerebral ischemia.

The aim of the study. To study the effect of a new derivative of 4-aminobutanoic acid (compound KGM-5) on the level of neurotransmitters, neurotransmitter amino acids and on the structural and functional state of the rat hippocampus under conditions of experimental cerebral ischemia.

\section{Research planning (methodology)}

In conditions of acute cerebrovascular accident (ACVA) develops an "ischemic cascade" with a number of pathobiochemical changes, which eventually lead to an imbalance of neurotransmitters and destructive changes or death of neurons, including in the hippocampus $[1,2,3,8]$. Given this, the study used an experimental model of ACVA, histological examination of neurons in the hippocampus and the effect of a new derivative of 4-aminobutanoic acid KGM-5 in comparison with the known GABA-ergic drug "Picamilon" on the level of neurotransmitters and neurotransmitter amino acids, which makes it possible to assess neuroprotective activity.

\section{Materials and methods}

The research was conducted on the basis of the Educational and Scientific Training Center for Medical and Biological Research of the Educational and Scientific Institute of Applied Pharmacy of the National University of Pharmacy (NUPh) during 2020-2021. During the experiment, the animals were in the vivarium of the NUPh training center at an air temperature of 20-22 ${ }^{\circ} \mathrm{C}$, natural light regime "day and night", in standard cages, on a standard diet.

The ACVA model was reproduced in rats by occlusion of the left common carotid artery [9] under conditions of thiopental anesthesia (sodium thiopental (35 $\mathrm{mg} / \mathrm{kg}$ ) intraperitoneally (i/p)). A total of 5 groups of animals were used: intact control group (IC, $n=6)$, group of animals with ACVA that were not treated (control pathology, CP, n=13); a group of animals with ACVA who were treated for 5 days after surgery (first administration 30 min after surgery) with the compound KGM-5 (ACVA + $\mathrm{KGM}-5, \mathrm{n}=14$ ) at a conditionally effective dose of $30 \mathrm{mg} / \mathrm{kg}$ body weight of animals administered $\mathrm{i} / \mathrm{p}$ [7] and a group of animals with ACVA (ACVA + CD "Picamilon", n=13), who received $\mathrm{i} / \mathrm{p}$ for 5 days comparison drug (CD) "Picamilon" (solution for injection $100 \mathrm{mg} / \mathrm{ml}$, manufactured by JSC "Pharmstandard UfaVITA", Russia) at a dose of $17 \mathrm{mg} / \mathrm{kg}$, which was calculated from the daily dose for humans $(200 \mathrm{mg} /$ day $)$ using the coefficient of species sensitivity [10]. "Picamilon" was chosen as a comparison drug as an analogue in structure, pharmacological action and by administration of the test compound, because among the nootropics available on the Ukrainian pharmaceutical market - GABA derivatives, there are no dosage forms for parenteral administration. The group of pseudo-operated animals (POA, $n=8$ ), which were operated without occlusion of the left common carotid artery, was used for comparison in histological studies. Withdrawal of animals from the experiment was performed on the 6th day after modelling ACVA (a day after the last injection of the studied drugs).
During the experiments, the principles of the Helsinki Declaration on the Humane Treatment of Animals (2000) and the Directive of the Council of the European Union on the protection of animals used for scientific purposes (2010) were followed [11, 12]. The number of animals used in the experiment was justified at a meeting of the commission on bioethics of the National University of Pharmacy (Minutes No. 5 of 25.03.2021).

The brains of half of the rats were fixed in $96^{\circ}$ ethanol immediately after removal from the cranial cavity, then a frontal incision was made at the level of the medial temporal region of the large hemispheres (for the study of the ventral hippocampus). The samples were poured into paraffin. Sections for examination microscopy were stained with hematoxylin and eosin [13]. To determine the functional activity of neurons used staining of sections with thionine by the method of Nissl [14]. In the pyramidal layer $\mathrm{CA}_{1}$ and $\mathrm{CA}_{3}$ of the $\mathrm{VG}$ zones, the neurons were quantified according to their functional state with the determination of the alteration index, which was calculated as the ratio of destructive neurons to unchanged per 100 cells and expressed in \%. All measurements were performed in the field of view of the microscope, followed by conversion to 100 cells and derived (ocular 10, lens 40) in 5 replicates. Separately in the photographs of the studied areas of VG (ocular 10, lens 20) using the program Toupcam Granum measured the area of perikaryon cells $\left(\mu \mathrm{m}^{2}\right)$. Examination of micropreparations was performed under a Granum light microscope, microphotography of microscopic images was performed with a digital video camera Granum DSM 310. Photographs were processed on a Pentium $2.4 \mathrm{GHz}$ computer using Toup View. The brain of the second half of rats immediately after removal from the cranial cavity was used to determine norepinephrine (NE) and dopamine (DA), serotonin, gamma-aminobutyric (GABA), aspartic, glutamic amino acids and glycine [15-17]. Statistical processing was performed using the program Statistica 6.0 (StatSoft, Inc., USA), checked the normality of the distribution using the W-Shapiro-Wills test. It was found that the data are subject to abnormal distribution, so we used the non-parametric Mann-Whitney U-test, the results were presented as the median (Me) and interquartile range (25-75 percentiles). The accepted level of significance is $\mathrm{p}<0.05$ [18].

\section{Research results}

In the hippocampus of vertebrates, including rats, among the neuronal layers, the most saturated with the bodies of neurons is the pyramidal layer. Its cells have a characteristic shape and a specific nature of dendritic discharge. According to the density and nature of the location of neurons, there are several functionally different zones: $\mathrm{CA}_{1}-\mathrm{CA}_{4}$. The most numerous cellular elements are localized in $\mathrm{CA}_{1}$ and $\mathrm{CA}_{3}$, areas involved in learning and memory [19]. The morphological picture of the $\mathrm{CA}_{1}$ and $\mathrm{CA}_{3}$ zones of the hippocampus was clearly topographic, and the characteristic structure of the pyramidal layer corresponded to the description of the cytoarchitectonic features of these zones in scientific sources [19-21].

In POA, the pyramidal layer of the $\mathrm{CA}_{1}$ zone was represented as a strip with fairly densely spaced 
(3-6 rows) neurons. The cells were medium in size, had a decorated nuclear membrane, distinct nucleoli. The nuclei were round, the perikaryon was round as well (Fig. 1, $a, b$ ). In the $\mathrm{CA}_{3}$ zone, the neurons of the pyramidal layer, in addition to spherical perikaryons, had elliptical and triangular perikaryons, were larger in size, had a clear nuclear membrane, nucleoli, and clear apical dendrites. Nissl's substance was evenly distributed in the neuroplasm of most pyramidal neurons of the $\mathrm{CA}_{1}$ and $\mathrm{CA}_{3}$ zones. Hyperchromic neurons with signs of body wrinkling and hypochromic cells were single (Fig. 2, $a, b$ ). The distribution of neurons by functional state in $\mathrm{CA}_{1}$ and $\mathrm{CA}_{3}$ zones, respectively, was as follows: $80.5 \%$ and $76.7 \%-$ normochromic neurons, $6.6 \%$ and $6.5 \%$ - hyperchromic cells, hypochromic $-9.4 \%$ and $8.7 \%$; hyperchromic pycnomorphic cells $-1.2 \%$ and $4.5 \%$; shadow cells $1.2 \%$ and $0 \%$. The alteration index of pyramidal neurons in $\mathrm{CA}_{1}$ and $\mathrm{CA}_{3}$ zones was 0.03 and 0.06 (Table 1). The area of the perikaryon of pyramidal neurons in these zones was 104.6 and $203.0 \mu^{2}$, respectively (Table 2).

In the pyramidal layer $\mathrm{CA}_{1}$ and $\mathrm{CA}_{3}$ of the rat hippocampal zone on day 6 after ACVA modelling (CP group), a decrease in the width of the pyramidal layer, neuron density, blurring of rows and disorganization of cells in rows, local "falling out" of rows was found. The shape of the cell bodies was changed, pericellular edema was observed (Fig. 1, $c, d$; Fig. 2, $c$, d). Polymorphic changes of chromatophilic substance in neurons: from local chromatolysis to pronounced hypochromia, the appearance of shadow cells; hyperchromatosis and hyperchromatosis with pycnomorphic signs were detected (Fig. 1, $c, d$; Fig. 2, $c, d)$. The distribution of neurons by functional state showed that unchanged pyramidal neurons in both studied zones $\left(\mathrm{CA}_{1}\right.$ and $\left.\mathrm{CA}_{3}\right)$ probably decreased by $17.1 \%$ and $26.5 \%(\mathrm{p}<0.05)$, respectively, compared with POA. The number of hypochromic neurons probably increased $(p<0.05)$ in the $\mathrm{CA}_{3}$ zone (by $52.9 \%$ ); shadow cells probably increased $(\mathrm{p}<0.05)$ in both study zones (in $\mathrm{CA}_{1}$ zone $7.8 \%$ vs. $1.2 \% \mathrm{POA}$ and in $\mathrm{CA}_{3}$ zone $10.6 \%$ vs. 0.0 $\%$ POA).

The number of cells with hyperchromatosis almost did not change, in contrast to hyperchromic pycnomorphic, which were more $(\mathrm{p}<0.05) 6.3$ times in the $\mathrm{CA}_{1}$ zone and 2.5 times in the $\mathrm{CA}_{3}$ zone compared with POA (Table 1).

The average area of perikaryons of pyramidal neurons of both studied zones decreased by $37.9 \%$ and $24.8 \%$, respectively (Table 2 ).

Table 1

Functional state of neurons of the pyramidal layer $\mathrm{CA}_{1}$ and $\mathrm{CA}_{3}$ zones of the ventral hippocampus of rats with the ACVA model under the influence of the studied drugs

\begin{tabular}{|c|c|c|c|c|}
\hline \multirow{2}{*}{$\begin{array}{c}\text { Structural and } \\
\text { functional types of } \\
\text { neurons, } \%\end{array}$} & \multicolumn{4}{|c|}{ Groups of rats } \\
\hline & $\begin{array}{l}\text { Pseudo-operated } \\
\text { animals (POA) }\end{array}$ & $\mathrm{CP}(\mathrm{ACVA})$ & $\begin{array}{c}\text { ACVA + KGM-5, } \\
30 \mathrm{mg} / \mathrm{kg} \\
\end{array}$ & $\begin{array}{c}\text { ACVA + CD } \\
\ll \text { Picamilon», } 17 \mathrm{mg} / \mathrm{kg}\end{array}$ \\
\hline \multicolumn{5}{|c|}{ Hippocampal area $-\mathrm{CA}_{1}$} \\
\hline Normochromic & $\begin{array}{c}80.5 \\
(77.8 ; 83.9)\end{array}$ & $\begin{array}{c}66.7 \\
(61.8 ; 70.6)^{*}\end{array}$ & $\begin{array}{c}80 \\
(77.5 ; 82.9)^{* *}\end{array}$ & $\begin{array}{c}73.5 \\
(72.4 ; 75) * / * *\end{array}$ \\
\hline Hyperchromic & $\begin{array}{c}6.6 \\
(5.8 ; 11.1)\end{array}$ & $\begin{array}{c}7.6 \\
(5.6 ; 8.8)\end{array}$ & $\begin{array}{c}6.6 \\
(4.9 ; 9.5)\end{array}$ & $\begin{array}{c}9.7 \\
(6.3 ; 10.7)\end{array}$ \\
\hline $\begin{array}{l}\text { Hyperchromic } \\
\text { pycnomorphic }\end{array}$ & $\begin{array}{c}1.2 \\
(0 ; 2.4)\end{array}$ & $\begin{array}{c}7.6 \\
(4.8 ; 12.5)^{*}\end{array}$ & $\begin{array}{c}1.3 \\
(0 ; 4.8)^{* *}\end{array}$ & $\begin{array}{c}3.7 \\
(2.9 ; 6.7) * / * *\end{array}$ \\
\hline Hypochromic & $\begin{array}{c}9.4 \\
(7.1 ; 11.4)\end{array}$ & $\begin{array}{c}9.1 \\
(7.6 ; 16.7)\end{array}$ & $\begin{array}{c}8.8 \\
(6.6 ; 11) \\
\end{array}$ & $\begin{array}{c}9.4 \\
(6.9 ; 10) \\
\end{array}$ \\
\hline Shadow cells & $\begin{array}{c}1.2 \\
(0 ; 3.4)\end{array}$ & $\begin{array}{c}7.8 \\
(6.6 ; 11)^{*}\end{array}$ & $\begin{array}{c}2.7 \\
(0 ; 3.7)^{* *}\end{array}$ & $\begin{array}{c}5.9 \\
(0 ; 6.9)^{* / * *}\end{array}$ \\
\hline Index alteration & $\begin{array}{c}0.03 \\
(0.02 ; 0.08) \\
\end{array}$ & $\begin{array}{c}0.24 \\
(0.19 ; 0.29)^{*}\end{array}$ & $\begin{array}{c}0.04 \\
(0.02 ; 0.08)^{* *}\end{array}$ & $\begin{array}{c}0.1 \\
(0.1 ; 0.2)^{* / * *}\end{array}$ \\
\hline \multicolumn{5}{|c|}{ Hippocampal area $-\mathrm{CA}_{3}$} \\
\hline Normochromic & $\begin{array}{c}76.7 \\
(72.9 ; 80.5)\end{array}$ & $\begin{array}{c}56.4 \\
(50 ; 66.7)^{*}\end{array}$ & $\begin{array}{c}57.5 \\
(54.1 ; 57.89)^{*}\end{array}$ & $\begin{array}{c}77.8 \\
(77 ; 79.8)^{* *}\end{array}$ \\
\hline Hyperchromic & $\begin{array}{c}6.5 \\
(4.4 ; 8.7) \\
\end{array}$ & $\begin{array}{c}6.8 \\
(2.6 ; 11.1) \\
\end{array}$ & $\begin{array}{c}8.3 \\
(4.4 ; 13.2) \\
\end{array}$ & $\begin{array}{c}8.1 \\
(5.5 ; 11.1) \\
\end{array}$ \\
\hline $\begin{array}{l}\text { Hyperchromic } \\
\text { pycnomorphic }\end{array}$ & $\begin{array}{c}4.5 \\
(2.2 ; 6.8)\end{array}$ & $\begin{array}{c}11.4 \\
(5.6 ; 15.2)^{*}\end{array}$ & $\begin{array}{c}9.1 \\
(7.5 ; 14.7)^{*}\end{array}$ & $\begin{array}{c}1.2 \\
(1.1 ; 2.7)^{* *}\end{array}$ \\
\hline Hypochromic & $\begin{array}{c}8.7 \\
(6.7 ; 9.8) \\
\end{array}$ & $\begin{array}{c}13.3 \\
(9.1 ; 19)^{*}\end{array}$ & $\begin{array}{c}14 \\
(12.1 ; 19.4)^{*}\end{array}$ & $\begin{array}{c}6.7 \\
(5.6 ; 9.9) \\
\end{array}$ \\
\hline Shadow cells & $\begin{array}{c}0.0 \\
(0 ; 5) \\
\end{array}$ & $\begin{array}{c}10.6 \\
(4.5 ; 16.7)^{*} \\
\end{array}$ & $\begin{array}{c}9.3 \\
(5.6 ; 14.3) *\end{array}$ & $\begin{array}{c}2.2 \\
(1.1 ; 3.4)^{* *}\end{array}$ \\
\hline Index alteration & $\begin{array}{c}0.06 \\
(0.03 ; 0.17)\end{array}$ & $\begin{array}{c}0.41 \\
(0.21 ; 0.5)^{*}\end{array}$ & $\begin{array}{c}0.36 \\
(0.26 ; 0.47)^{*}\end{array}$ & $\begin{array}{c}0.05 \\
(0.03 ; 0.07)^{* *}\end{array}$ \\
\hline
\end{tabular}

Note: * - differences are statistically significant for the POA group, $p<0,05 ; * *$-differences are statistically significant for the CP group, $p<0,05$ 
The area of the perikaryon of neurons of the pyramidal layer $\mathrm{CA}_{1}$ and $\mathrm{CA}_{3}$ zones of the ventral hippocampus of rats with the ACVA model under the influence of the studied drugs

\begin{tabular}{|l|c|c|}
\hline \multicolumn{1}{|c|}{ Experimental groups } & Area, $\mu \mathrm{m}^{2}$ & Hippocampal area \\
\hline Pseudo-operated animals (POA) & $104.6(88.4 ; 118.6)$ & \multirow{3}{*}{ CA $_{1}$} \\
\cline { 1 - 2 } Control pathology (CP) & $65.0(46.3 ; 72.2)^{*}$ & \\
\hline ACVA + KGM-5, 30 mg/kg & $90.8(82.6 ; 115.3)^{* *}$ & \multirow{2}{*}{ CA $_{3}$} \\
\hline ACVA + CD "Picamilon", $17 \mathrm{mg} / \mathrm{kg}$ & $115.6(98.7 ; 124.6)^{* *}$ & \\
\hline Pseudo-operated animals (POA) & $203.0(159 ; 231.8)$ & \\
\hline Control pathology (CP) & $152.6(140.9 ; 201.9)^{*}$ & \\
\hline ACVA + KGM-5, 30 mg/kg & $162.8(133.6 ; 184.2)^{*}$ & \\
\hline ACVA + CD "Picamilon", $17 \mathrm{mg} / \mathrm{kg}$ & $164.2(133.5 ; 188.8)$ & \\
\hline
\end{tabular}

Note: *-differences are statistically significant for the POA group, $p<0.05 ; * *$-differences are statistically significant for the POA group, $p<0.05$
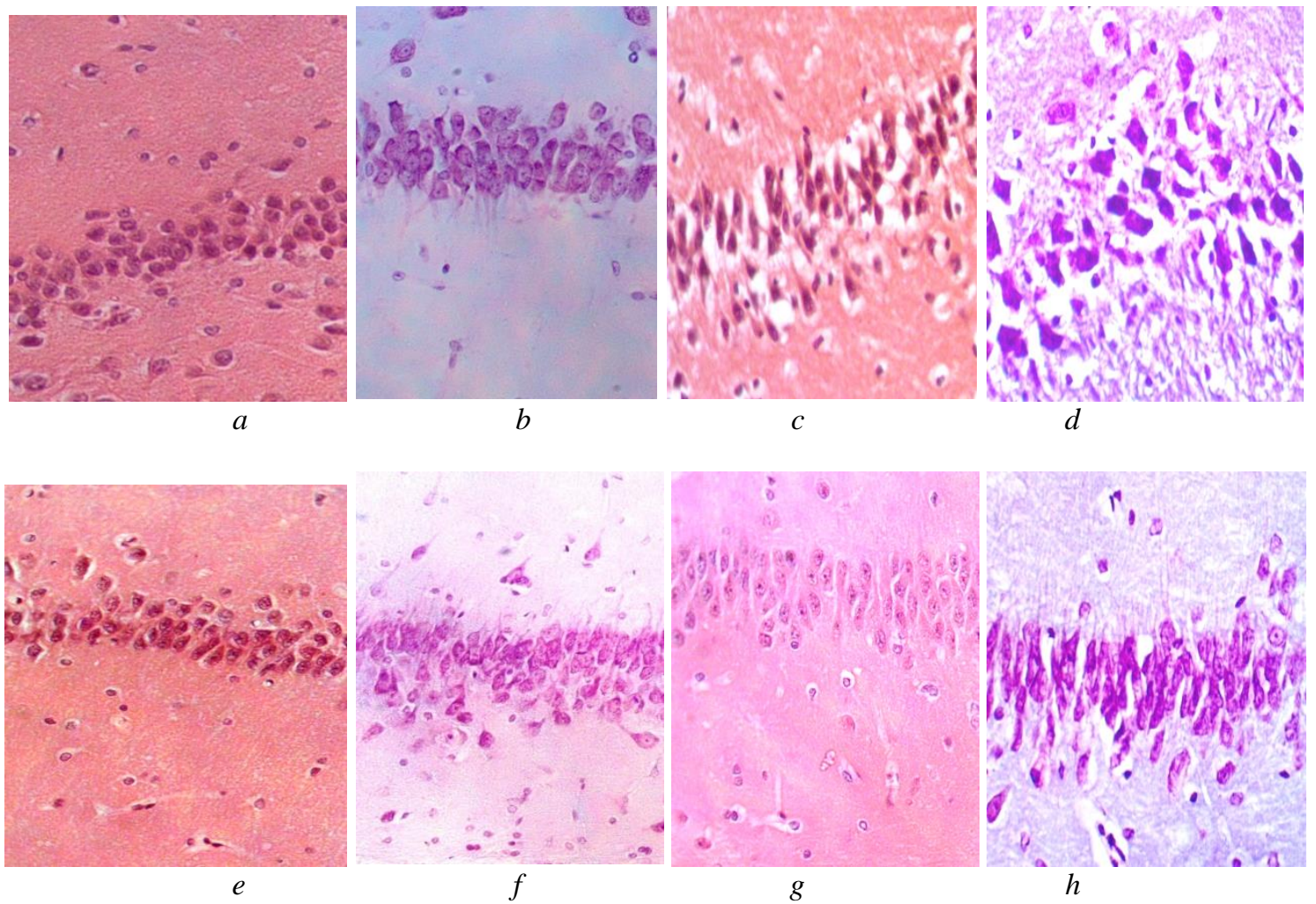

Fig. 1. Zone $\mathrm{CA}_{1}$ of the ventral hippocampus: $\mathrm{a}$, b: pseudo-operated animals: $a$-rows of neurons of round shape (hematoxylin-eosin. $\times 250$ ); $b$ - the state of the tigroid substance in the neuroplasm of the vast majority of neurons corresponds to normal (thionin by the method of Nissl. $\times 250$ ); $c, d$ - rats with ACVA for 6 days after modelling (c-disorganization, decrease in the density of neurons, "loss" of cells from the rows, pericellular edema, $\mathrm{d}-$ the predominance of hyperchromic and hyperchromic pycnomorphic neurons (thionine by the method of Nissl. $\times 250$ ); $e$, $f$-rats with ACVA, which were treated with the compound KGM-5 (30 mg/kg) (e - restoration of the architecture of the series, the density of neurons in the series (hematoxylin-eosin. $\times 250$ ), $f$ - the state of the tigroid in the neuroplasm of the vast majority of cells normal (thionin by the method of Nissl. $\times 400$ ); $f, g$ - rats with ACVA, which were treated with

CD "Picamilon" $(17 \mathrm{mg} / \mathrm{kg}): g$ - restoration of the structure of the pyramidal layer (hematoxylin-eosin. $\times 250)$, $h$ - normochromic and hyperchromic neurons (thionine by the method of Nissl. $\times 400$ )

Against the background of treatment of KGM-5 rats with $\mathrm{ACVA}$, it was found that in the $\mathrm{CA}_{1}$ zone of the hippocampus, the width of the pyramidal layer was restored in most areas, the density of neurons in the row was significantly increased, the order of the rows was also restored. Most neurons had a characteristic shape that was identical to that in POA (Fig. 1, $d, e$ ). In some places, pericellular edema was preserved. Morphometric parameters in the $\mathrm{CA}_{1}$ zone of the hippocampus, as well as the area of the perikaryon of neurons, were close to the values of POA (Table1, 2). In the $\mathrm{CA}_{3}$ zone of the hippocampus of rats with ACVA treated with the compound KGM-5, some areas containing neurons with signs of dystrophic changes, cell prolapse were detected (Fig. 2, d). During thionine staining, almost the entire spectrum of functional states of pyramidal neurons was detected (Fig. 2,e). The alteration index was at the level of CP $(\mathrm{p}>0.05)$. 

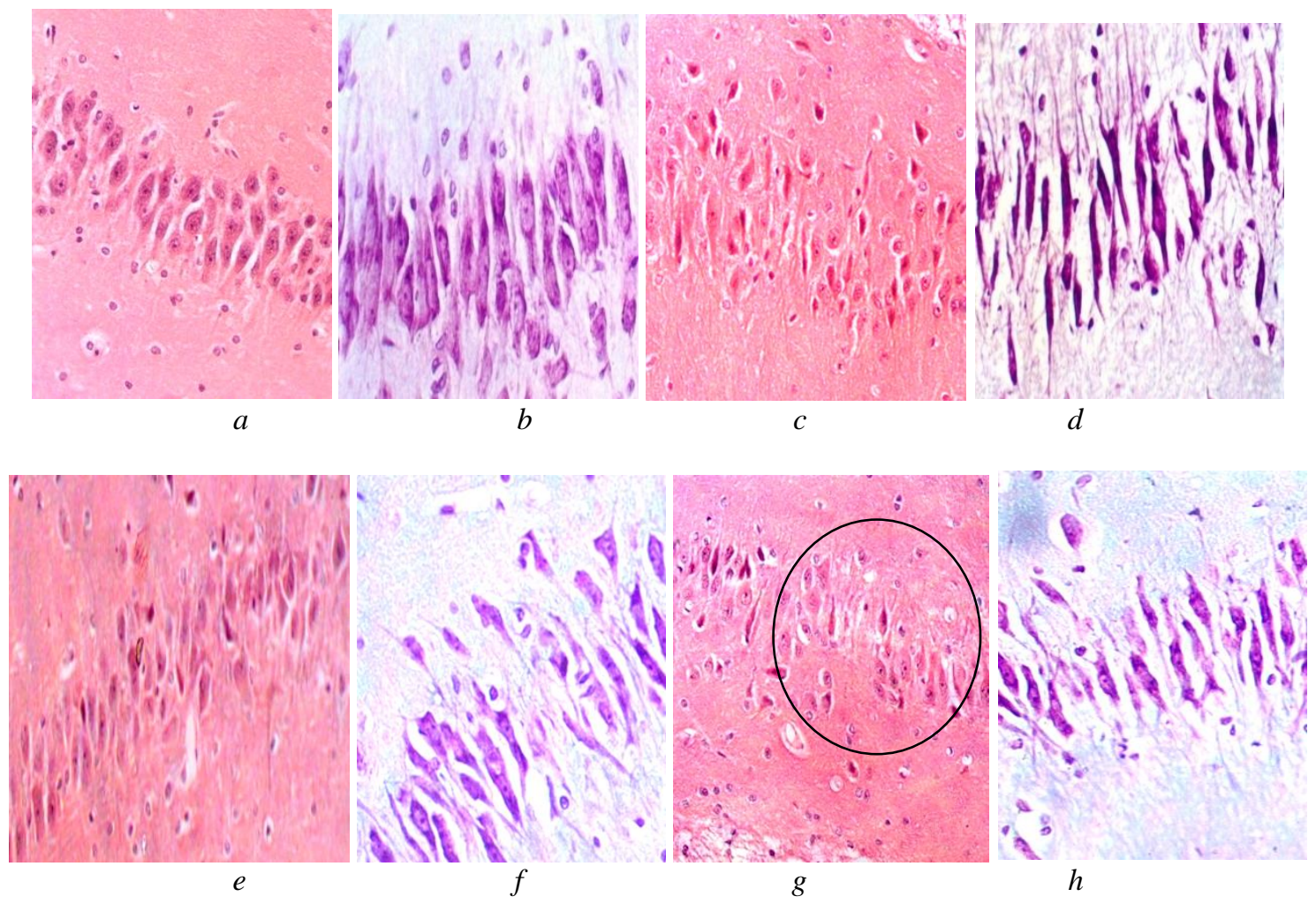

Fig. 2. Zone $\mathrm{CA}_{3}$ of the ventral hippocampus: $a, b$ : pseudo-operated animals ( $a$-rows of large polygonal neurons (hematoxylin-eosin. 250); b - the state of the tigroid substance in the neuroplasm of the vast majority of neurons corresponds to normal (thionin by the method of Nissl. $\times 250$ ); $c, d$-rats with ACVA on the 6th day after modelling (c-disorganization, decrease in neuronal density, "loss" of cells from rows, pericellular edema, change in shape and size of neurons; $\mathrm{d}$ - predominance of hypochromic neurons (thionine by the method of Nissl. $\times 250 ; e, f$-rats with

ACVA, which were treated with the compound KGM-5 $(30 \mathrm{mg} / \mathrm{kg}) ;(e-$ restoration of the architecture of the series, the density of neurons in the series) (hematoxylin-eosin. $\times 250) ; g, h$-rats with ACVA, which were treated CD

"Picamilon" (17 mg/kg): $g$ - violation of the cytoarchitectonics of the layer, the loss of neurons from the series (hematoxylin-eosin. $\times 250$ ); $h$ - almost unaltered area with normochromic and hypochromic neurons (thionin by the method of Nissl. $\times 250$ )

In the $\mathrm{CA}_{1}$ zone of the hippocampus of rats with ACVA after treatment with CD "Picamilon" changes in the pyramidal layer in width, the density of neurons located in it were virtually absent. The state of the tigroid was normochromic or moderately hyperchromic (Fig. 1, $g, h)$. In the $\mathrm{CA}_{3}$ zone of the hippocampus near virtually unchanged areas with loosening and prolapse of cells, changes in their shape and pronounced eosinophilic staining of the neuroplasm were detected (Fig. 2, g, $h$ ). The state of the tigroid was normochromic or hypochromic with the addition of individual hyperchromic cells. When a number of neurons were disturbed, hyperchromic, hyperchromic pyknotic cells, and shadow cells predominated. A number of cells with pronounced chromatolysis were detected (Fig. 2, $h$ ). Morphometric parameters that characterize the functional state of the neurons of the pyramidal layer $\mathrm{CA}_{3}$ of the hippocampal zone, probably did not differ from those in CP (Table 1), as well as the area of cell perikaryon (Table 2).

The results of the study of the effect of the studied drugs on the level of excitatory (glutamine, asparagine) and inhibitory (GABA, glycine) neuroamino acids and neurotransmitters in the brain of rats with ACVA are given in Table 3.

In the brain tissue of rats with the ACVA model compared to IC, a significant increase in the level of excitatory neurotransmitter amino acids glutamic and aspartic was found, respectively, $26.0 \mathrm{vs} .12 .7 \mu \mathrm{mol} / \mathrm{g}$ of tissue $(p<0.05)$ and 8.2 vs. $6.3 \mu \mathrm{mol} / \mathrm{g}$ of tissue $(p<0.05)$ and a significant decrease in the inhibitory amino acids GABA and glycine, respectively, 0.7 against $2.9 \mu \mathrm{mol} / \mathrm{g}$ of tissue $(\mathrm{p}<0.05)$ and 0.7 against $1.7 \mu \mathrm{mol} / \mathrm{g}$ of tissue $<0.05$ ) (Table 3). The compound KGM-5 significantly reduced the level of excitatory neurotransmitter amino acids glutamine and asparagine, respectively, $14.1 \mathrm{vs.}$ $26.0 \mu \mathrm{mol} / \mathrm{g}$ of tissue $(\mathrm{p}<0.05)$ and $6.9 \mathrm{vs} .8 .2 \mu \mathrm{mol} / \mathrm{g}$ of tissue $(\mathrm{p}<0.05)$ and a significant increase in the inhibitory amino acids GABA and glycine, respectively, 2.9 against $0.7 \mu \mathrm{mol} / \mathrm{g}$ of tissue $(\mathrm{p}<0.05)$ and 1.2 against $0.7 \mu \mathrm{mol} / \mathrm{g}$ of tissue $(p<0.05)$. Under the influence of KGM-5, the level of aspartic acid and glycine was restored almost to the level of IC. The effect of the new KGM-5 shelf on the content of neuroamino acids in the brain tissue of rats with the ACVA model was the same as the effect of the comparison drug "Picamilon". 
Table 3

The content of neuroamino acids in the brain tissue of rats with the ACVA model

\begin{tabular}{|c|c|c|c|c|c|}
\hline Experimental groups & Intact control (IC) & $\begin{array}{l}\text { Control pathology } \\
\text { (ACVA) }\end{array}$ & $\begin{array}{c}\text { ACVA + KGM-5, } \\
30 \mathrm{mg} / \mathrm{kg}\end{array}$ & $\begin{array}{c}\mathrm{ACVA}+\mathrm{CD} \\
\text { «icamilon», } 17 \\
\mathrm{mg} / \mathrm{kg}\end{array}$ & $\mathrm{p}$ \\
\hline $\begin{array}{l}\text { Glutamic acid, } \\
\mu \mathrm{mol} / \mathrm{g} \text { of tissue }\end{array}$ & $\begin{array}{c}12.7 \\
(12.3 ; 13.0)\end{array}$ & $\begin{array}{c}26.0 \\
(25.8 ; 26.6)^{*}\end{array}$ & $\begin{array}{c}14.1 \\
(13.7 ; 14.5) * / * *\end{array}$ & $\begin{array}{c}14.0 \\
(13.9 ; 14.1)^{* / * *}\end{array}$ & 0.0012 \\
\hline $\begin{array}{l}\text { Aspartic acid, } \\
\mu \mathrm{mol} / \mathrm{g} \text { of tissue }\end{array}$ & $6.3(5.9 ; 6.4)$ & $\begin{array}{c}8.2 \\
(8.0 ; 8.4)^{*}\end{array}$ & $\begin{array}{c}6.9 \\
(6.7 ; 7.2)^{* *}\end{array}$ & $\begin{array}{c}6.4 \\
(6.4 ; 6.6)^{* *}\end{array}$ & 0.0027 \\
\hline $\begin{array}{l}\text { GABA, } \mu \mathrm{mol} / \mathrm{g} \text { of } \\
\text { tissue }\end{array}$ & $2.9(2.9 ; 3.0)$ & $\begin{array}{c}0.7 \\
(0.7 ; 0.7)^{*}\end{array}$ & $\begin{array}{c}2.9 \\
(2.9 ; 2.9)^{* *}\end{array}$ & $\begin{array}{c}3.4 \\
(3.0 ; 3.4)^{* *}\end{array}$ & 0.0018 \\
\hline $\begin{array}{l}\text { Glycine, } \mu \mathrm{mol} / \mathrm{g} \text { of } \\
\text { tissue }\end{array}$ & $\begin{array}{c}1.7 \\
(1.5 ; 1.9)\end{array}$ & $\begin{array}{c}0.7 \\
(0.7 ; 0.7)^{*}\end{array}$ & $\begin{array}{c}1.2 \\
(1.1 ; 1.3)^{* / * *}\end{array}$ & $\begin{array}{c}1.2 \\
(1.2 ; 1.3) * / * *\end{array}$ & 0.0020 \\
\hline $\begin{array}{l}\text { Norepinephrine, } \mu \mathrm{g} / \mathrm{g} \\
\text { of tissue }\end{array}$ & $\begin{array}{c}0.8 \\
(0.8 ; 0.8)\end{array}$ & $\begin{array}{c}2.0 \\
(2.0 ; 2.1)^{*}\end{array}$ & $\begin{array}{c}0.9 \\
(0.7 ; 0.9)^{* *}\end{array}$ & $\begin{array}{c}0.9 \\
(0.9 ; 0.9)^{* *}\end{array}$ & 0.0020 \\
\hline $\begin{array}{l}\text { Dopamine, } \mu \mathrm{g} / \mathrm{g} \text { of } \\
\text { tissue }\end{array}$ & $\begin{array}{c}1.1 \\
(0.1 ; 1.1)\end{array}$ & $\begin{array}{c}1.7 \\
(1.7 ; 1.7)^{*}\end{array}$ & $\begin{array}{c}1.3 \\
(1.3 ; 1.3)^{* / * *}\end{array}$ & $\begin{array}{c}1.3 \\
(1.3 ; 1.3)^{* / * *}\end{array}$ & 0.0039 \\
\hline $\begin{array}{l}\text { Serotonin, } \mu \mathrm{g} / \mathrm{g} \text { of } \\
\text { tissue }\end{array}$ & $\begin{array}{c}0.3 \\
(0.3 ; 0.4)\end{array}$ & $\begin{array}{c}0.5 \\
(0.4 ; 0.5)\end{array}$ & $\begin{array}{c}0.4 \\
(0.3 ; 0.4)\end{array}$ & $\begin{array}{c}0.4 \\
(0.4 ; 0.4)^{* *}\end{array}$ & 0.0413 \\
\hline
\end{tabular}

Note: $p$ - the level of statistical significance when comparing samples using ANOVA analysis of variance; * level of statistical significance compared to IC (Mann-Whitney test), $p<0.05$; ** - level of statistical significance compared to CP (Mann-Whitney test), $p<0.05$

In the brain tissue of rats with the ACVA model compared with IC, a significant decrease in the level of neurotransmitters norepinephrine and dopamine was found $(2.0$ vs. $0.8 \mu \mathrm{g} / \mathrm{g}$ tissue $)(\mathrm{p}<0.05)$ and $1.27 \mathrm{vs}$. $1.1 \mu \mathrm{g} / \mathrm{g}$ tissue $(\mathrm{p}<0.05)$ and a slight (unreliable, $\mathrm{p}>0.05$ ) increase in serotonin levels ( 0.5 vs. $03 \mu \mathrm{g} / \mathrm{g}$ tissue) $(p>0.05)$. The comparison drug "Picamilon" restored the content of norepinephrine and dopamine to the level of IC and significantly $(\mathrm{p}<0.05)$ compared with $\mathrm{CP}$ reduced the level of dopamine. The effect of the new compound KGM-5 on the level of neurotransmitters in the brain tissue of rats with the ACVA model was similar to that of CD "Picamilon", but KGM-5 did not show a significant effect on serotonin levels.

\section{Discussion of research results}

According to the literature $[22,23]$, regardless of the cause of ACVA always develops a cascade of pathobiochemical changes or "ischemic cascade", the main links of which are:

- reduction of cerebral blood flow (energy deficit); excess glutamate, glutamate "excitotoxicity";

- intracellular accumulation of calcium ions; activation of intracellular enzymes; increasing the generation of reactive oxygen species, activation of free radical processes ("oxidative stress");

- expression of early response genes;

- "long-term" consequences of ischemia (local inflammation reactions, microvascular disorders, damage to the blood-brain barrier);

- necrosis, apoptosis and other forms of neuronal death.

Numerous data from experimental and clinical studies indicate the effectiveness of ACVA pharmacotherapy and its effects by affecting the GABA system [22-24]. It has been established that GABA-ergic substances, in particular the drug "Picamilon", can improve the blood supply to the brain; improve autoregulation of cerebral blood flow; suppress the glutamate-calcium cascade; prevent lipid peroxidation and increase the activity of antioxidant systems; have a membrane-protective effect; improve glucose utilization and eliminate energy deficiency and prevent destructive changes in neurons [23]. These data make obvious the prospects for the development of effective neuroprotectors based on GABA-ergic substances, one of which is a new derivative of 4-aminobutanoic acid - a compound under the code KGM-5, for which proven antiamnestic and antihypoxic activity [7].

It is known that the hippocampus provides the implementation of memory mechanisms, reactions associated with behaviour, performs the function of recording emotionally significant events [19, 20]. Vascular disorders such as ACVA cause changes in brain neurons, particularly in the hippocampus [6, 21, 22]. In our experiment, it was found that in the pyramidal layer of $\mathrm{CA}_{1}$ and $\mathrm{CA}_{3}$ zones of the hippocampus of rats with ACVA, the shape of the bodies of neurons was changed, pericellular edema was observed. A probable increase in structurally altered neurons in both zones of the hippocampus and an increase in the index of their alteration were found. This suggests that ACVA, caused by occlusion of the left carotid artery, resulted in destructive changes in rat hippocampal neurons.

Under the influence of the compound KGM-5 - a new derivative of 4-aminobutanoic acid, in the $\mathrm{CA}_{1}$ zone of the hippocampus, the number of normochromic neurons increased by $20 \%$. The number of hyperchromic cells reached the level of POA, hypochromic neurons decreased by $3.3 \%$, although not likely. Hyperchromic pycnomorphic neurons and shadow cells were probably 5.8 and 2.9 times smaller than CP. The alteration index of neurons decreased 6 times (Table 1), which indicates the neuroprotective effect of the test compound. The area of the perikaryon of these neurons increased by $39.7 \%$ (Table 2). The increase in binuclear neurons in combination with a certain increase in the area of the perikaryon is a morphological manifestation of regenerative processes and an increase in the functional activity of cells [25]. In the $\mathrm{CA}_{1}$ zone of the hippocampus under the influence of CD "Picamilon" the percentage of 
normochromic neurons increased by $16.6 \%$, hyperchromic pycnomorphic and shadow cells - decreased by 6.3 and 3.5 times, respectively, the alteration index - by 4.8 times (Table 4), the area of the perikaryon of these neurons increased 1.8 times (Table 5).

Both drugs showed a less pronounced normalizing effect on the $\mathrm{CA}_{3}$ area of the hippocampus: under the influence of KGM-5 the index of alteration of neurons was at the level of $\mathrm{CP}$, under the influence of $\mathrm{CD}$ "Picamilon" the area of the perikaryon of neurons was at the level of CP.

In ACVA conditions, an imbalance of excitatory (glutamine and asparagine) and inhibitory (GABA and glycine) neurotransmitter amino acids and a decrease in the level of neurotransmitters norepinephrine and dopamine were found. The comparison drug "Picamilon" restored the disturbed balance of excitatory (glutamine and asparagine) and inhibitory (GABA and glycine) neurotransmitter amino acids in ACVA and reduced the neurotransmitters norepinephrine and dopamine and increased serotonin to intact levels. The obtained results coincide with the data that GABA-ergic drugs, in particular "Picamilon", reduce the neurotoxic effect of the glutamate-ergic system by increasing the activity of the GABA system [24, 25]. The new compound KGM-5 showed a CD-like effect of "Picamilon" on the level of neurotransmitter amino acids and neurotransmitters in ACVA rats, had a protective effect on the state of neurons, which suggests its normalizing effect on brain energy processes, which requires further study.

Thus, the obtained results indicate a neuroprotective effect of a new derivative of 4-aminobutanoic acid - the compound KGM-5, in ACVA in rats.
Study limitations. In this study, the level of only some mediators was investigated, which limits the conclusions in this regard.

Prospects for further research. In the future, it is advisable to study the effect of KGM-5 on the level of acetylcholine in the brain under the conditions of this model.

\section{Conclusions}

Changes in the levels of neurotransmitter amino acids and neurotransmitters were detected in the brains of ACVA rats, and cytotoxic changes were detected in the neurons of the pyramidal layer $\mathrm{CA}_{1}$ and $\mathrm{CA}_{3}$ of the hippocampal zones.

Therapeutic administration of KGM-5 increases the survival of pyramidal neurons in the studied areas of the brain, reducing the relative proportion of irreversibly altered cells and helps to restore impaired levels of neurotransmitter amino acids and neurotransmitters (norepinephrine, dopamine and serotonin) in the brain of rats with ACVA.

The neuroprotective effect of the new compound KGM-5 corresponds to that GABA-ergic drug comparison "Picamilon".

\section{Conflict of interests}

The authors declare that they have no conflicts of interest.

\section{Acknowledgment}

The authors thank the staff of the Educational and Scientific Institute of Applied Pharmacy of NUPh for their support and advice in conducting the experiment.

\section{References}

1. Mischenko, T. S. (2017). Cognitive violations in the practice of family doctor (theurgency of the problem, risk factors, pathogenesis,treatment options and preventions). Family Medicine, 1 (69), 21-25. doi: http://doi.org/10.30841/2307-5112.1(69).2017.102983

2. Kovalchuk, V. V. (2020). Cognitive Dysfunction. A Modern View on Etiology, Pathogenesis, Diagnostics and Therapy. Effektivnaia farmakoterapiia, $16(31), 40-52$.

3. Lokshina, A. B. (2020). Modern aspects of diagnosis and treatment of mild cognitive impairment. Russian Journal of Geriatric Medicine, 3, 199-204. doi: http://doi.org/10.37586/2686-8636-3-2020-199-204

4. Sahathevan, R., Brodtmann, A., Donnan, G. A. (2011). Dementia, Stroke, and Vascular Risk Factors; a Review. International Journal of Stroke, 7 (1), 61-73. doi: http://doi.org/10.1111/j.1747-4949.2011.00731.x

5. Levin, O. S. (2014). Diagnostika i lechenie dementsii v klinicheskoi praktike. Moscow: MEDpressinform, 256.

6. Kovalchuk, V. V., Barantsevych, E. R. (2017). Chronic Cerebral Ischemia. Current Understanding of Etiopathogenesis, Diagnostics and Therapy. Effektivnaia farmakoterapiia, 19, 26-32.

7. Mishchenko, O. Ya., Holik, M. Yu., Hrytsenko, I. S., Komisarenko, A. M., Palahina, N. Yu., Mishchenko, M. V. (2017). Pat. No. 120512 UA. Zastosuvannia pokhidnykh 4- aminobutanovoi kysloty yak nootropnykh zasobiv. MPK: (206), A 61K 31/197, A61P 25/00. No. u201703627; declareted: 13.04.2017; published: 10.11.2017, Bul. No. 21.

8. Gantsgorn, E. V., Khloponin, D. P., Khloponin, P. A. (2015). Nootropics and melaxen' neuroprotectional activity morphopharmacological analysis in rats' acute cerebral ischemia. Medical Herald of the South of Russia, 3, 42-46.

9. Mironov, A. N.; Mironov, A. N. (Ed.) (2012). Rukovodstvo po provedeniiu doklinicheskikh issledovanii lekarstvennykh sredstv. P. 1. Moscow: Grif i K., 944.

10. Ulanova, I. P., Sidorov, K. K., Khalepo, A. I. K. (1968). K voprosu ob uchete poverkhnosti tela eksperimentalnykh zhivotnykh pri toksikologicheskom issledovanii. Toksikologiia novykh promyshlennykh khimicheskikh veschestv, 10, 18-25.

11. Pro zatverdzhennia Poriadku provedennia doklinichnoho vyvchennia likarskykh zasobiv (2009). Nakaz MOZ Ukrainy No. 944. 14.12.2009. Available at: https://zakon.rada.gov.ua/laws/show/z0053-10\#Text

12. European convention for the protection of vertebrate animal used for experimental and other scientific purposes (1986). Stratsburg: Council of Europe, 11.

13. Merkulov, H. A. (1969). Kurs patolohohystolohycheskoi tekhnyky. Moscow: Medytsyna Lenynhr. otd-nye, 424.

14. Pyrs, E. (1962). Hystokhymyia: teoretycheskaia y prykladnaia. Moscow, 962.

15. Kogan, B. M., Nechaev, N. V. (1979). Chuvstvitelnii i bystrii metod odnovremennogo opredeleniia dofamina, noradrenalina, serotonina i 5-oksiindol-uksusnoi kisloty v odnoi probe. Laboratornoe delo, 5, 301-303.

16. Zaitseva, T. N., Tiuleneva, I. N. (1958). Metod khromatograficheskogo razdeleniia aminokislot. Laboratornoe delo, 3, 24-30.

17. Drozdov, N. S., Materanskaia, N. P. (1970). Praktikum po biologicheskoi khimii. Moscow: Vysshaia shkola, 296. 
18. Rebrova, O. Iu. (2006). Statisticheskii analiz meditsinskikh dannykh. Primenenie paketa programm Statistica. Moscow: MediaSfera, 312.

19. Tverskaia, A. V., Dolzhikov, A. A., Bobyntsev, I. I., Kriukov, A. A., Belykh, A. E. (2014). Morfologicheskie izmeneniia neironov oblastei SA1 I SA3 gippokampa krys pri khronicheskom stresse (morfometricheskoe issledovanie). Chelovek i ego zdorove, 3, 37-41.

20. El Falougy, H., Kubikova, E., Benuska, J. (2008). The microscopical structure of the hippocampus in the rat. Bratisl. Lek Listy, 109 (3), 106-110.

21. Gordon, R. Ya. (2014). Peculiarities of neurodegeneration in hippocampus fieldsafter kainic acid action in rats. Tsitologiya, 56 (12), 919-925.

22. Gantsgorn, E. V., Khloponin, D. P., Maklyakov, Yu. S. (2013). Pathophysiological basics of acute brain ischemia modern pharmacotherapy. nootropics and antioxidants' role in neuroprotection. Medical Herald of the South of Russia, 2, 4-12.

23. Belenichev, I. F., Bukhtiiarova, N. V., Sereda, D. A. (2010). Sovremennye napravleniia neiroprotektsii v terapii ostrogo perioda patologii golovnogo mozga razlichnogo reneza. Mezhdunarodnii nevrologicheskii zhurnal, 2 (32). Available at: http://www.mif-ua.com/archive/article/11994

24. Chekman, Y. S., Belenychev, Y. F., Demchenko A. V. et. al. (2014). Nootropics in a comlex therapyof chronic cerebral ischemia. Nauka ta innovatsii, 10 (4), 61-75.

25. Martynova, O. V. (2017). Vliianie farmakologicheskogo prekonditsioni-rovaniia s ispolzovaniem ingibitora FDE-5 tadalafila na ishemicheskie - reperfuzionnye povrezhdeniia golovnogo mozga krys (eksperimentalnoe iscledovanie). Belgorod, 147.

Received date 09.03.2021

Accepted date 21.04.2021

Published date 30.04.2021

Oksana Mishchenko, Doctor of Pharmaceutical Sciences, Professor, Department of Clinical Pharmacology, Institute of Advanced Training of Pharmacy Specialists, National University of Pharmacy, Pushkinska str., 53, Kharkiv, Ukraine, 61002

E-mail: mishchoksana@gmail.com

Natalia Palagina, Postgraduate Student, Department of Clinical Pharmacology, Institute of Advanced Training of Pharmacy Specialists, National University of Pharmacy, Pushkinska str., 53, Kharkiv, Ukraine, 61002

E-mail: clinpharmacol_ipksph@nuph.edu.ua

Yuliia Larianovskaya, PhD, Senior Researcher, Educational and Scientific Institute of Applied Pharmacy, National University of Pharmacy. Pushkinska str., 53, Kharkiv, Ukraine, 61002

E-mail: Yulashechka@rambler.ru

Tatyana Gorbach, PhD, Associate Professor, Department of Biological Chemistry, Kharkiv National Medical University, Nauky ave., 4, Kharkiv, Ukraine, 61022

E-mail: v-gorbatch@yandex.ua

Khomenko Viktor, Doctor of Pharmaceutical Sciences, Professor, Department of Pharmacy and Pharmacology, Donetsk National Medical University, Pryvokzalna str., 27, Lyman, Ukraine, 84404

E-mail: khomenko_donnmu@ukr.net

Nataliia Yasna, PhD, Associate Professor, Department of Chemistry, Technology and Pharmacy, T. H. Shevchenko National University "Chernihiv Colehium", Hetmana Polubotka str., 53, Chernihiv, Ukraine, 14013

E-mail: yasnaya.nata1@gmail.com 